Pengaruh Patahan dan ...

\title{
PENGARUH PATAHAN DAN INDUKSI SEISMIK PADA SISTEM GEOTHERMAL STUDI KASUS LAPANGAN GEOTHERMAL KAMOJANG
}

\author{
Anik Hilyah, Widya Utama \\ Teknik Geofisika, ITS \\ Email: anik.hilyah@gmail.com
}

\begin{abstract}
Abstrak. Kamojang merupakan salah satu lapangan geothermal yang sampai saat ini secara aktif di eksploitasi. Untuk itu pemeliharaan reservoar sangat penting dilakukan yang salah satunya melalui monitoring mikroseismik. Monitoring mikroseismik lapangan geothermal Kamojang secara kontinyu dilakukan untuk mengetahui bagaimana fluida injeksi berperan pada pembentukan hydrofracturing dan pengaruh struktur seismogenic terhadap reservoar. Struktur seismogenic seperti patahan berperan penting dalam recharge dan untuk keberlanjutan sistem geothermal. Patahan juga berperan sebagai media pelepasan energi seismik selama injeksi fluida maupun selama eksploitasi. Penelitian ini menjelaskan aktivitas mikroseismik yang terekam selama satu tahun yang dapat dibedakan dari rekaman gempa karena aktivitas tektonik. Hydrofracturing yang terbentuk sebagian besar terkonsentrasi di sekitar area geothermal sedangkan distribusi spasial hiposenter yang menunjukkan pelepasan energi seismik sebagian besar terdapat pada elevasi $0-3 \mathrm{~km}$ dimana terjadi perubahan fase dari air menjadi uap pada reservoar geothermal.
\end{abstract}

Kata Kunci: geothermal; induksi seismik; Kamojang

\begin{abstract}
Kamojang is one of the geothermal field that actively exploited. Reservoir maintenance is very important to do, by way of microseismic monitoring. Microseismic monitoring Kamojang geothermal field is continuously conducted to determine how fluid injection hydrofracturing role in the formation and effect of seismogenic structures of the reservoir. Seismogenic structures such as faults play an important role in the recharge and for the sustainability of the geothermal system. Fault also act as a medium of seismic energy release during fluid injection and during exploitation. This study describes the recorded microseismic activity during one year that can be distinguished from the earthquake due to tectonic activity. Hydrofracturing formed largely concentrated around the geothermal area while the spatial distribution of hypocenter which shows the seismic energy release are mostly found at an elevation of $0-3 \mathrm{~km}$ where there is a phase change from water to steam in the geothermal reservoir.
\end{abstract}

Keywords: geothermal; seismic induction; Kamojang

\section{PENDAHULUAN}

Induksi seismik saat ini telah banyak digunakan untuk teknologi bawah permukaan yaitu pada eksploitasi hidrokarbon, sistem geothermal dan pertambangan. Struktur seismogenic seperti patahan banyak ditemukan di berbagai kedalaman kerak bumi dengan ukuran dan frekuensi yang berbeda-beda pada lingkungan tektonik yang berbeda pula. Pada kerak bagian atas dekat dengan permukaan bumi, patahan banyak ditemui sebagai jalan aliran fluida yang memungkinkan adanya injeksi fluida ke dalam reservoar.

Injeksi fluida bisa berasal dari injeksi buatan maupun injeksi alami dari pergerakan fluida bawah permukaan. Injeksi fluida di sekitar patahan dapat menimbulkan tekanan pada pori. Tekanan pada pori diasosiasikan dengan timbulnya aktivitas seismik yang dikenal sebagai induksi seismik. Tekanan pada pori yang terjadi di sekitar zona patahan dirumuskan dengan persamaan Terzaghi berikut ini:

$$
\tau=C-\mu\left(\sigma_{n}-p\right)
$$

Dimana $\tau$ adalah shear stress,

$C$ adalah kohesi,

$\mu$ adalah koefisien friksi,

$\sigma_{n}$ adalah normal stress terhadap bidang patahan, dan

$p$ adalah tekanan fluida.

Berdasarkan persamaan (1), jika tekanan pada pori kecil maka akan meningkatkan shear stress pada patahan dan mengunci segmen patahan. Namun pada tahap eksploitasi akan terjadi 
kompaksi terhadap reservoar yang menyebabkan bertambahnya stress pada patahan. Pada akhirnya bertambahnya stress tersebut akan menyebabkan patahan aktif kembali dan menimbulkan aktivitas seismik. Stress yang terakumulasi pada segmensegmen patahan akan menyebabkan aktivitas seismik di sekitar patahan yang dikenal sebagai deformasi tektonik lokal (Borgia et al. 2000).

Kejadian induksi seismik yang terjadi pada operasi geothermal telah lama diteliti. Pada umumnya, penelitian-penelitian yang telah dilakukan menunjukkan, bahwa injeksi pada batuan sedimen menghasilkan sedikit aktivitas seismik daripada injeksi pada batuan kristalin. Aktivitas seismik yang terekam mempunyai magnitudo $0-3$ skala Richter. Stress local atau regional mempunyai peranan penting pada induksi seismik yang disebabkan injeksi bawah permukaan. Sedangkan rekahan dan patahan mempunyai peranan penting dalam pergerakkan fluida (permeabilitas) dan perubahan stress pada kerak bumi.

Penelitian ini berasumsi eksploitasi geothermal akan menyebabkan stress terakumulasi secara kontinyu pada patahan dan pada akhirnya stress tersebut akan terlepas melalui coseismic strain.
Hydro-fracturing yang terbentuk dapat dikorelasikan dengan injeksi fluida atau produksi fluida dari reservoar geothermal.

\section{Struktur Geologi Lapangan Kamojang}

Lapangan panas bumi Kamojang merupakan bagian dari kompleks gunung api yang memanjang dari Barat ke Timur yang terdiri atas rangkaian Gunung Rakutak, Danau Ciharus, Sistem Danau Pangkalan, Gunung Gandapura, Gunung Guntur, dan Gunung Masigit. Dilihat dari tingkat erosinya, rangkaian vulkanik ini tumbuh dari arah Barat menuju Timur dengan Gunung Rakutak tertua serta Gunung Guntur termuda (Robert 1988). Berdasarkan peta geologi lapangan panas bumi Kamojang (Gambar 1) oleh divisi geothermal Pertamina Pusat (1975) bahwa struktur geologi daerah ini dikontrol oleh dinding kaldera pangkalan di sisi Barat, kelompok sesar normal berarah Barat Laut - Tenggara di bagian Utara dan sesar normal yang berarah Utara - Selatan di sisi Timur. Sesar normal Utara - Selatan ini mengontrol pertumbuhan beberapa kawah seperti Leutak, Wakong, Saar, Manuk, dan Pojok, yang merupakan kelurusan manifestasi panas bumi di permukaan.

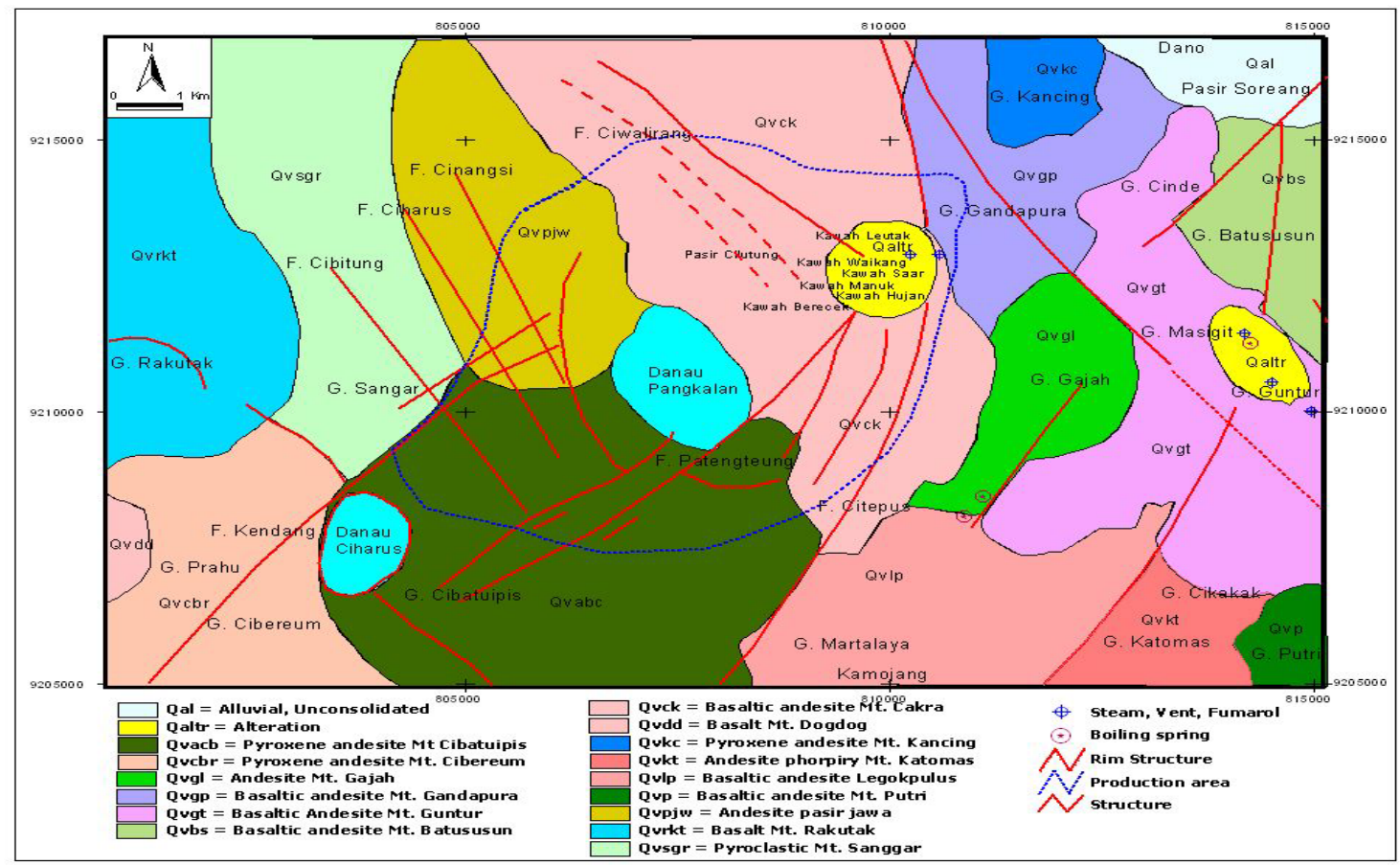

Gambar 1. Peta Geologi Area Geothermal Kamojang \& Sekitarnya (Pertamina AG Kamojang, 2000) 


\section{Eksploitasi Geothermal}

Eksplorasi lapangan panas bumi Kamojang telah dimulai pada tahun 1918. Aktifitas penelitian dilanjutkan dengan pemboran berkedalaman $128 \mathrm{~m}$ di tahun 1926. Eksplorasi terpadu yang dilakukan sejak tahun 1964 menunjukkan lapangan Kamojang adalah lapangan sistem uap kering dengan potensi 300 MWe. Penyelidikan geofisika terpadu dilakukan dari tahun 1972 hingga 1974 (Hochstein 1976). Lima pemboran eksplorasi dilakukan, dan dikembangkan hingga lebih 20 sumur produksi dengan hasil daya listrik 30 MWe (Sudarman \& (Hochstein 1983). Hingga tahun 1981, atas bantuan pemerintah Selandia Baru, pengembangan lapangan Kamojang mencapai $55 \mathrm{MWe}$. Hingga saat ini kapasitas total pembangkit listrik tenaga panas bumi (PLTP) sebesar $200 \mathrm{MW}$.

Saat ini telah banyak survei yang telah dilakukan untuk pengembangan lapangan geothermal Kamojang salah satunya adalah survei micro earthquake (MEQ) atau mikroseismik yang secara rutin dilakukan untuk memonitor sistem reservoar.

\section{Hydraulic Fracturing}

Data yang dikumpulkan dalam penelitian ini adalah hasil pengamatan selama satu tahun dari bulan Maret 2004 sampai Februari 2005 di daerah sekitar lapangan panas bumi Kamojang dengan menggunakan jaringan stasiun mikroseismik yang dipasang oleh Pertamina. Dalam periode tersebut telah terjadi ratusan kali gempa yang terdiri dari mikroseismik dan gempa jauh. Gempa jauh merupakan istilah yang dipakai untuk mendefinisikan gempa dengan magnitudo lebih besar dari 3 skala Richter. Gempa jauh diasosiasikan oleh pergerakan lempeng tektonik.

Data gempa pada penelitian ini adalah kejadian gempa yang tercatat setidaknya oleh tiga stasiun pengamatan gempa. Pada lapangan panas bumi Kamojang terdapat empat stasiun pengamatan gempa yang terletak di sekitar Kmj-32, CHR-A, Kmj-7 dan Kmj-25. Dari keempat stasiun pengamatan gempa tersebut telah dikumpulkan data untuk area panas bumi Kamojang tercatat 181 kali kejadian gempa dengan gempa mikro sebanyak 177 dan gempa jauh sebanyak 4 kali.

Durasi mikroseismik secara umum berkisar antara 20 - 40 detik pada frekuensi $20 \mathrm{~Hz}$. Pada frekuensi yang lebih rendah yaitu $0,6-4 \mathrm{~Hz}$ yang terekam hanya gelombang Rayleigh, tidak ada pengukuran terhadap waktu tiba gelombang $\mathrm{P}$ dan S. Mikroseismik yang terjadi berhubungan dengan dinamika pengisian fluida pada rekahan. Peristiwa seperti ini sering terjadi di sistem geothermal, area vulkanik dan glasier. Dinamika fluida tersebut juga menyebabkan reaktivasi rekahan

\section{Pembahasan}

Mikroseismik telah sering diterapkan untuk monitoring pada area geothermal. Hiposenter berkorelasi dengan batuan berintensitas rekahan tinggi yang merupakan zona sirkulasi hidrotermal. Terkadang zona dengan intensitas rekahan tinggi tersebut juga tampak sebagai patahan aktif. Analisa tectonic setting dan rekaman aktivitas seismik pada area geothermal sangat berguna untuk penentuan kriteria eksploitasi.

Lapangan geothermal pada umumnya memiliki luas sekitar $10 \mathrm{~km}^{2}$, namun gempa dengan magnitudo besar yang diakibatkan patahan bisa berasal dari ratusan km jauhnya. Sehingga untuk penyelidikan gempa yang berhubungan dengan aktivitas geothermal hanya mempertimbangkan magnitudo dengan skala kecil (0-3 SR). Karakteristik lain area geothermal adalah adanya body magmatic seperti pluton atau dyke yang terbentuk dekat permukaan dan dibatasi oleh patahan utama yang terbentuk selama proses tektonik. Pada kasus lapangan geothermal yang berasosiasi dengan jajaran gunung api, seperti pada studi kasus lapangan Kamojang, patahan utama terbentuk di dalam area vulkanik dan struktur kompresi ditemukan di sekeliling patahan tersebut.

Dari data pengamatan kejadian gempa selama satu tahun, (Gambar 2) terdapat gempa jauh pada area dengan radius sekitar $30 \mathrm{~km}$ dengan magnitudo rata-rata $5,2 \mathrm{SR}$, sedangkan mikroseismik yang terjadi pada area geothermal mempunyai magnitudo rata-rata 1,1 SR. Berdasarkan data aktivitas gempa harian selama satu tahun, maka aktivitas gempa lapangan geothermal Kamojang diprediksi akan berlangsung secara kontinyu dalam waktu lama dan akan terjadi gempa dengan magnitudo kecil pada tahap awal eksploitasi. 


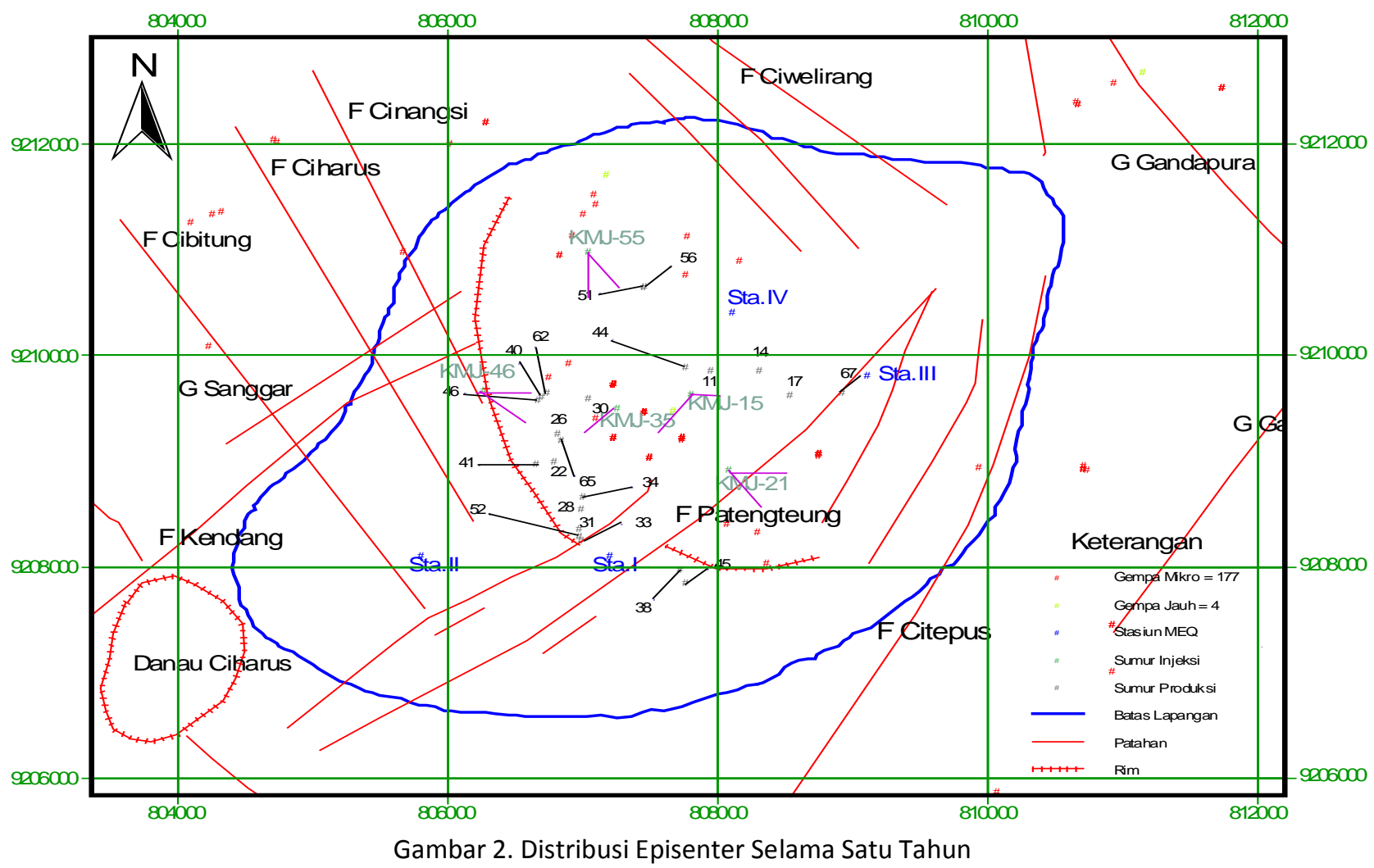

Distribusi vertikal penyebaran pusat-pusat gempa berhubungan dengan kedalaman dan jalur sesar, sehingga dapat menunjukkan dugaan adanya sesar aktif pada zona-zona lemah tersebut. Pada area geothermal Kamojang distribusi hiposenter terletak pada elevasi $0,02 \mathrm{~km}$ sampai dengan -17,01 $\mathrm{km}$. Hiposenter sebagian besar berada di bawah zona reservoar dan sebagian lagi tepat di zona reservoar, yaitu gempa dengan elevasi 0 sampai 3 $\mathrm{km}$ (Gambar 3). Jika diperhatikan, penyebaran gempa dengan hiposenter dangkal tersebut, ternyata posisi penyebarannya tidak jauh dari sumber geothermal dan mengelompok di sekitar sumur eksploitasi.
Jelas bahwa mikroseismik yang terjadi pada kedalaman tersebut diperkirakan penyebabnya berupa aktifitas dan proses-proses yang terjadi di reservoar tersebut, seperti transfer panas fluida yang berlangsung terus-menerus, sedangkan pada bagian yang lebih dalam, penyebaran pusat gempa lebih merata dan tidak berpola dengan frekuensi yang lebih rendah. Umumnya gempa jauh berada pada kedalaman ini. Hal ini diperkirakan penyebabnya dari aktifitas sesar yang lebih dalam atau pengangkatan oleh sumber panas seperti magma yang diselingi oleh aspek tektonik regional. 


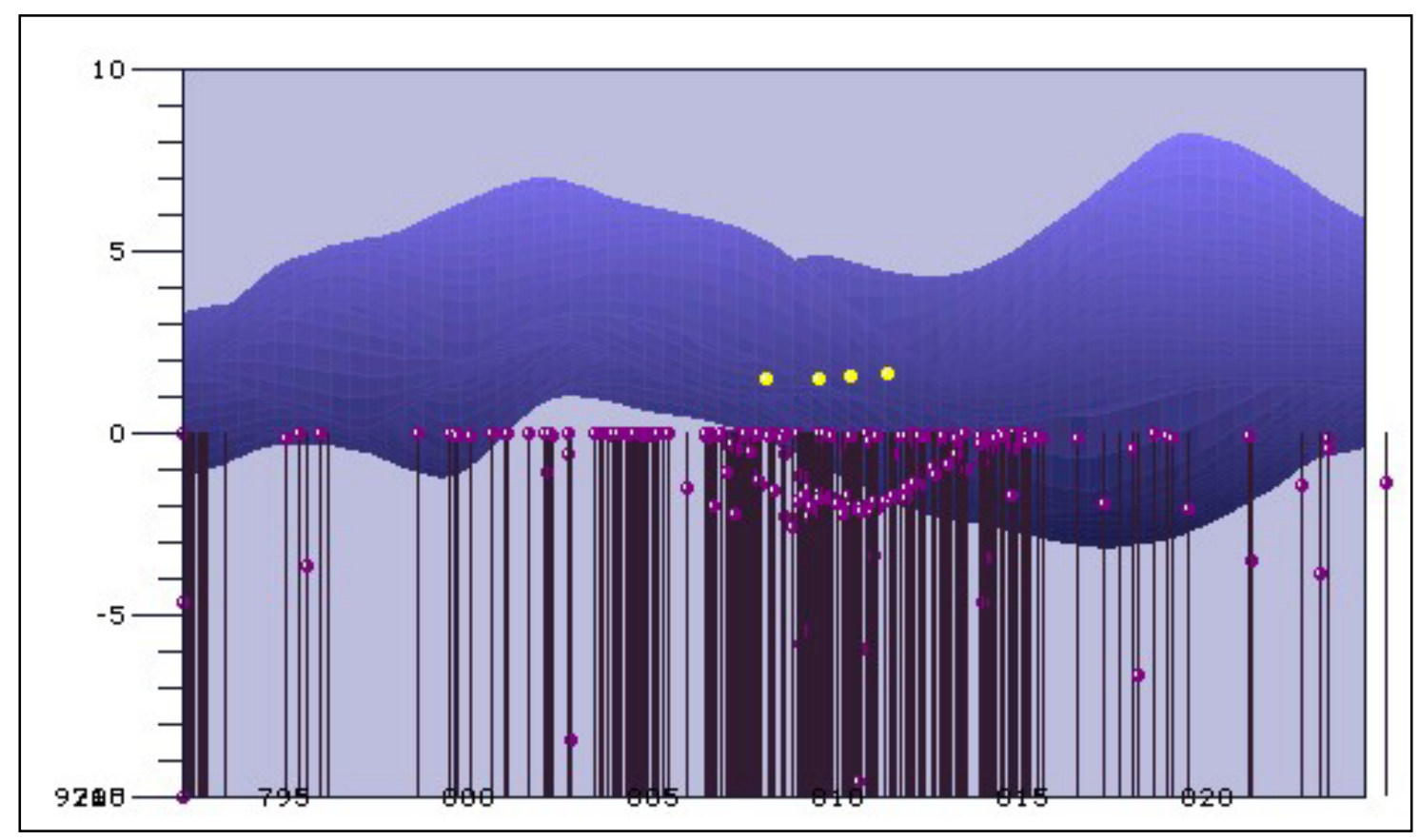

Gambar 3. Penampang Hiposenter Barat - Timur Area Panas Bumi Kamojang dan Sekitarnya Hasil Pengolahan dengan MEQ-Software.

Namun ada juga beberapa gempa jauh yang terletak dekat dengan permukaan hingga sampai $20 \mathrm{~m}$ yang letaknya diluar lapangan panas bumi Kamojang. Sedangkan gempa jauh pada daerah lapangan panas bumi Kamojang letaknya sangat dalam sekitar lebih dari $-20 \mathrm{~km}$.

\section{KESIMPULAN}

Induksi seismic pada area geothermal disebabkan oleh dua hal. Pertama disebabkan oleh pelepasan energi akibat injeksi fluida melalui patahan menuju reservoar. Kedua karena perubahan fase air menjadi uap di dalam reservoar geothermal. Induksi seismik tersebut terekam sebagai mikroseismik dengan distribusi hiposenter bervariasi. Hiposenter pada elevasi 0,02 sampai dengan $-17,01 \mathrm{~km}$ berada di zona reservoar dan hiposenter pada elevasi 0 sampai $-3 \mathrm{~km}$ terletak di bawah zona reservoar. Penampang hiposenter menunjukkan akumulasi dengan kemiringan Barat Daya - Timur Laut yang sesuai dengan pola struktur zona patahan. Sedangkan diluar zona tersebut banyak terjadi gempa jauh karena aspek tektonik.

\section{DAFTAR PUSTAKA}

API, 1993. Geothermal Reservoir Engineering. Volume 2, Jakarta: PT Loka Datamas Indah.

API, 1999. Klasifikasi Potensi Energi Panasbumi. Jakarta: Media API edisi September.

API, 2003. A Silver Year of Indonesian Geothermal Development - A Lesson Learn. Proceeding of The $6^{\text {th }}$ Indonesian Geothermal Association - Annual Meeting and Conference, Bandung.

David Gubbins, 1990. Seismology and Plate Tectonics. Cambridge University Press, University of Leeds, Cambridge.

John M.Reynolds, 1997. An Introduction to Applied and Enviromental Geophysics. UK: John Wiley \& Sons.

L. Rybach, L.J.P.Muffler, 1981. Geothermal System: Principles and Case Histories, Great Britain: John Wiley \& Sons.

Malcolm A. Grant, lan G.Donaldson, Paul F.Bixley, 1982. Geothermal Reservoir Engineering. London: Academic Press.

Muh. Yustin Kamah, 2004. Laporan Periodik Monitoring Gempa Mikro (MEQ) Desember 2003 - Juli 2004. Geoscience Engineering, Pertamina Area Geothermal Kamojang. 
Prof. Manfred P.Hochstein, 2000. Geophysical Methods: Exploration of Mineral Deposit. Geophysical Courses Series, HAGI, Bandung.

R.E. Sherif, L.P.Geldart, 1995. Exploration Seismology. Melbourne: Cambridge Press, University of Houston. Stephen A. Onacha. Locating High Production Wells in East Africa Region Using Joint Geophysical Imaging (JGI) Methods-GEF/UNEP Funded Project, www.unep.org, Duke University USA. 